\title{
Contamination in a Microbiological Laboratory
}

\author{
Endeshaw Abatenh*, Birhanu Gizaw, Zerihun Tsegaye \\ Ethiopian Biodiversity Institute, Department of Microbiology, Comoros Street, 0000, Addis Ababa, Ethiopia
}

*Corresponding Author: Endeshaw Abatenh, Ethiopian Biodiversity Institute, Department of Microbiology, Comoros Street, 0000, Addis Ababa, Ethiopia

\begin{abstract}
Contamination is a clearly-established problem with serious consequences in the biological laboratory. It can be divided into three main categories (physical, chemical, and biological). The most common biological encountered contaminates are bacteria, molds, yeasts, viruses, mycoplasma, as well as cross contamination by other cell lines. This review provides an overview of major critical source and control options of contaminants. The critical source of contamination is suddenly or deliberately introduction of contaminants on the desired system during the beginning up to ending of laboratory work. To overcome the challenge numerous strategies must be daily exercised such as obtaining pure and viable cells from reputable gene banks; checking the characteristics of the culture periodically, and practicing good aseptic technique, and using antibiotics routinely. In general, this paper suggested that possible to reduce or eliminate contamination frequency and seriousness by visual inspection of the culture within a few days of it becoming infected.
\end{abstract}

Keywords: Contamination, Source, Control, and Effect

\section{INTRODUCTION}

Contamination is undesired introduction of impurities like chemical, microbial or physical matter, into or onto a starting or intermediating cell culture during sampling, holding, processing, storing, transferring, packaging and transporting. A cell culture contaminant is defined as some element in the culture system that is undesirable because of its possible adverse effects on either the system or its use. Contamination of cell cultures is easily the most common problem encountered in several microbial laboratories, sometimes with very serious consequences. In overall, the reason for contaminants are mostly happened through avoidable procedural errors and misguide techniques. Microbes are widely distributed in the environment without restriction and they are involved in different places even inside a laboratory. Microbial contamination is one of a biggest worldwide obstacle for researchers working with microbial cultures. It may lose laboratory valuable strains. False - positive cultures are reports of microbiological laboratory came from due to common and unusual laboratory contaminants. High microbial contaminate concentration is happened in a microbial lab due to lack of proper management. It is a global concern regarding health and leads to difficult for getting accurate research output. It is manually or systematically introduce in our culture and damage the quality of our work. Recently, many articles are mentioned it and previous reports act as evidence for the challenge. In the end, in order to reduce their first apply good laboratory practice next follow appropriate instructions [2, 6, 7 and 12].

Contaminates are receiving high attention, but the sources and processes of them are not well understood. The major methodological part of the study on the basis of an observational cohort study and long year visual investigation experience in the work area (laboratory). The aim of the current study was identified the critical sources of bacterial contamination inside laboratory then it forward answers for causes of cross-contamination how it happens? The purpose of this paper to describe appropriate and necessary options to prevent microbial, physical or chemical cross-contamination and to reduce false positive culture reports as well as to maximize the true result comes from the microbiological laboratory through practical techniques.

\section{TYPES OF CELL-CULTURE CONTAMINATION}

\subsection{Physical Contaminants}

Physical contaminants are materials consider as natural or artificial components that act as a contaminant. It also termed as unwanted foreign bodies such as glass fragments, metal, stone, plastics, 
extraneous vegetable matter, hair, fibers, pipettes, storage equipment's, instruments, aluminum foil or paper residues and dust particles of incubator left by disinfectants or detergents are grouped here.

\subsection{Chemical Contamination}

Chemical contamination is defined as the presence of any non-living substance that results in undesirable effects on the culture system. It is useless for cell-culture at any circumstance leads to cell death. It may produce toxicity at all. Impurities found in media, sera, water, metal ions, endotoxins, free radicals, detergents, and germicides or pesticides residues are main components. In addition to this, unnecessary Impurities in gases used in carbon dioxide incubators are included.

\subsection{Biological Contamination}

Biological contaminants are living, subdivided into many division such as bacteria, molds, yeasts, viruses, algae, protozoa, Invertebrates, it becomes facilitated within cross contamination by other cell lines. Contamination by microbial species, which may spread via physical means (sharing media and reagents, using unplugged pipettes, improper handling and use of non-sterile reagents, accidental spilling or abnormal contact with the inanimate object) and biological means(direct or indirect contact on hands). Any types of microbial laboratories are sensitive to biological contamination. Hence, the airborne microorganisms can easily transfer, enter and outgrow desired cells in culture. The reason behind this is the presence of a high microbial load and good cultural practices are not followed [12].

\section{SOURCES OF CONTAMINATION}

\begin{tabular}{|c|c|c|}
\hline No. & Potential source of contamination & Reference \\
\hline 1 & $\begin{array}{l}\text { - Field-collected sample components and sampling site. } \\
\text { - Insufficient sample size and selection errors. } \\
\text { - Improper sample collection and processing equipment's like plastic or metal neck } \\
\text { tube or test tub, dissecting kit, flasks, beakers, forceps, pipettes, ice box, glass wares } \\
\text { and laminar air flow cabinet }\end{array}$ & \multirow[t]{9}{*}{$\begin{array}{l}{[1-3,5,6,8} \\
9-11,13,15- \\
17,19-21 \\
\text { and } 24]\end{array}$} \\
\hline 2 & $\begin{array}{l}\text { - Excessive internal and external abiotic components (heat, cold, sunlight, moisture). } \\
\text { - Originated from laboratory sinks, air, dust particles, benches, floors, tables, rooms, } \\
\text { water sources, and incubator. }\end{array}$ & \\
\hline 3 & $\begin{array}{l}\text { - Insect infestation, especially mites. They can move in air currents. The cultures are } \\
\text { contaminated due to the mite traveling in and out of the culture vessels. Insects can be } \\
\text { introduced into the lab by personnel (on hair, clothing, shoes). }\end{array}$ & \\
\hline 4 & $\begin{array}{l}\text { - Use of reduced shelf-life media. } \\
\text {-Deteriorated reagent, solution, chemicals, and water used for preparing media. } \\
\text {-Use of materials that fail to meet acceptance specifications. } \\
\text { calibration of utensils and equipment failure. } \\
\text { - Supplies or resource shortage. }\end{array}$ & \\
\hline 5 & $\begin{array}{l}\text { - Introduce un authorized and unskilled personnel for collection, identification, } \\
\text { characterization and preservation of sample in all units. } \\
\text { - Uneducated background that haven't enough ability to perform requested specific tasks. }\end{array}$ & \\
\hline 6 & $\begin{array}{l}\text { - Creation of aerosol or splashing and outbreaks during specimen processing. In } \\
\text { addition to this, Aerosols that fall out during transportation and incubation }\end{array}$ & \\
\hline 7 & $\begin{array}{l}\text { - Processing excessive number of specimens in one batch due to staff shortages may } \\
\text { lead to the breakdown in protocol adherence and invite potential error for cross- } \\
\text { contamination }\end{array}$ & \\
\hline 8 & $\begin{array}{l}\text { - Contaminates have a various way of entry into work and stock culture. Especially, it } \\
\text { may escape from our integumentary and respiratory system due to several reasons: } \\
\text { Inadequate personnel cleanliness, insufficient skin disinfection, and poor hand hygiene, } \\
\text { inadequate laboratory gowning and personal protective equipment like a surgical or } \\
\text { disposable glove and coat all these are mentioned by different researchers. }\end{array}$ & \\
\hline 9 & $\begin{array}{l}\text { - Improper selecting, storing and handling of cell culture, identification instruments, } \\
\text { electronic computer, mobile phone and other input machines. } \\
\text {-Weak manufacturing facility. } \\
\text { - Rough floors, walls, and ceilings. } \\
\text { - Lack of air filtration systems. } \\
\text { - Improper lighting and ventilation. } \\
\text { - Poorly located vents, ledges, and drains. } \\
\text { - Inadequate washing, cleaning, toilet, and locker facilities to allow for sanitary } \\
\text { operation. }\end{array}$ & \\
\hline
\end{tabular}




\begin{tabular}{|l|l|l|}
\hline 10 & $\begin{array}{l}\text { - Using and disposing sharp tools for dissection and cutting broken glass, needles, or } \\
\text { razor blades. } \\
\text { - Chemical and heat burns or fire. }\end{array}$ \\
\hline 11 & $\begin{array}{l}\text { - Mislabeling, poor communication, overwork due to busy work schedule. } \\
\text { - Lack of concentration may be tension or confusion, bran and health psychological } \\
\text { disorders. } \\
\text { - Malpractices such as eating food, drinking beverages, or using illegal drugs. }\end{array}$ \\
\hline 12 & - Impurities in gases used in carbon dioxide incubators. \\
\hline 13 & $\begin{array}{l}\text { - Misguided study design, experimental set up and culturing protocol. - Out of the } \\
\text { scientific basis of investigation and follow-up. } \\
\text { - Undesired spend time and energy for laboratory trials. }\end{array}$ \\
\hline
\end{tabular}

\section{THE CONTROL MECHANISM OF CONTAMINATION}

\begin{tabular}{|c|c|c|}
\hline No. & $\begin{array}{r}\text { Control mechanism } \\
\end{array}$ & Reference \\
\hline 1 & $\begin{array}{l}\text { - Follow your facility's written policy. } \\
\text { - Don't pour chemicals down the drain. } \\
\text { - Cleaning and decontaminating should be performed at the ending and beginning of } \\
\text { the day. }\end{array}$ & \multirow[t]{8}{*}{$\begin{array}{l}{[1,2,4,6,10} \\
11,13,14,18, \\
\text { and } 23]\end{array}$} \\
\hline 2 & $\begin{array}{l}\text { - Apply sterilization methods like autoclave at } 121^{\circ} \mathrm{C} \text { for } 20 \mathrm{~min} \text { and hot air oven at } \\
160^{\circ} \mathrm{C} \text { for } 1 \mathrm{~h} \text {, micro or ultra-filtration, incinerator, ultraviolet rays, flame, formalin, } \\
\text { and ethanol. } \\
\text {-The use of sterile equipment's and environment helped to prevent further } \\
\text { contamination of the given sample. Even materials are covered through sterile } \\
\text { aluminum foil have a crucial role in the quality of research outcome. }\end{array}$ & \\
\hline 3 & $\begin{array}{l}\text { - Maintain laboratory environment. Firstly, exposed for fumigation. Secondly, } \\
\text { continued air sampling for microbiological evaluation. Thirdly, adjusted all } \\
\text { laboratory physical factors (Attain room ventilation system that replaces fresh air in } \\
\text { air filtration path), Fourthly, free from human unwanted influence and disturbance } \\
\text { finally reduce opportunities for an accident. }\end{array}$ & \\
\hline 4 & $\begin{array}{l}\text { - Make sure that both media bottles and flasks are dry and wiped with } 70 \% \text { alcohol } \\
\text { or } 5 \% \text { sodium hypochlorite before they are available for further preparation and } \\
\text { putting into the hood. } \\
\text { - Avoid leaving bottles opened for a long time which contain (media, solutions and } \\
\text { so on) close after use it immediately. }\end{array}$ & \\
\hline 5 & $\begin{array}{l}\text { - Proper instrument installing, packaging and handling } \\
\text { - Checking validation date of items. }\end{array}$ & \\
\hline 6 & $\begin{array}{l}\text {-Work carefully in aseptic condition at the time of sample collecting and processing. } \\
\text {-Clean the work area with disinfectant to prepare a safe and sterile workspace: } \\
\text { - Specimens and pouches should be handled one-at-a-time. } \\
\text { - Sample decontamination } \\
\text { - } \quad \text { Handling of only one cell line at a given time. }\end{array}$ & \\
\hline 7 & $\begin{array}{l}\text { - Reduce the opportunity for cell culture accidents the main possible solutions are } \\
\text { assigning with clear label of color ink, a written procedure, good supervision, } \\
\text { assigned tasks, careful planning and, backups }\end{array}$ & \\
\hline 8 & $\begin{array}{l}\text { - Follow up inoculation and other aseptic procedures. } \\
\text { - Aseptic transfer of cultures and sterile solutions. } \\
\text { - Preparing inoculants and cultures for study use. } \\
\text { - Use stock culture for short and long term and kept in appropriate temperature as } \\
\text { well as test the stock for sterility before reviving. } \\
\text { - Working with only one cell line at a time in order to prevent cross- contamination } \\
\text { effectively. } \\
\text { - Do not leave feeding culture on lab benches for a long time. } \\
\text { - Sealing culture vessels must be done. If an insect problem is in progress to control } \\
\text { it by using insecticides, plaster and plastic box. Commonly, Parafilm is used to wrap } \\
\text { culture vessels. } \\
\text { - An observational screen of viable cells regularly and check the characteristics of } \\
\text { the cell lines periodically for the presence of contamination. Screen all types of new } \\
\text { cells as they enter the lab, before and after cells are thawed, it is important to select } \\
\text { unrequired suspects before the paper publicized. } \\
\text { - An additional subculture of mixed and contaminated bacterial culture by using } \\
\text { numerous techniques or else discard contaminated culture. }\end{array}$ & \\
\hline
\end{tabular}




\begin{tabular}{|c|c|}
\hline 9 & $\begin{array}{l}\text { - Proper pipetting technique ensures that the accurate volume is aspirated and } \\
\text { dispensed and avoids splashing when dispensing liquid. } \\
\text { - Keep reactions and components capped whenever possible }\end{array}$ \\
\hline 10 & $\begin{array}{l}\text { - Using selective and have shelf-life media for preparation and further tasks. } \\
\text { - Never store media and organisms in cold facilities with light. } \\
\text { - Addition of growth inhibition substances in the medium }\end{array}$ \\
\hline 11 & $\begin{array}{l}\text { - Aerosols can lead to cross-contamination from sample-to-sample. } \\
\text { - Aerosol-resistant pipette tips have a barrier, which acts as a seal when exposed to } \\
\text { potential liquid contaminants, trapping them inside the barrier. }\end{array}$ \\
\hline 12 & $\begin{array}{l}\text { - Training personnel for a relevant specific target of decontamination protocols. } \\
\text { - Providing extra time for each lab lesson and spend a lot of time protecting } \\
\text { themselves inside the laboratory. } \\
\text { - Always wear personal protective equipment. Wear full sleeved coats, such that the } \\
\text { coats are kept inside the culture room and worn only after having a good ultra-violate } \\
\text { bath for at least } 30 \text { minutes. } \\
\text { - Unidirectional workflow with personnel and material. }\end{array}$ \\
\hline 13 & $\begin{array}{l}\text { - Keep work surfaces and materials neat and orderly } \\
\text { - Avoid clutter. } \\
\text { - Use small containers when possible } \\
\text { - Return reagents and others in its original place after finished activity } \\
\text { - Clean up facility should be performed routinely. This includes floors, ceilings, and } \\
\text { walls } \\
\text { - Empty bins regularly } \\
\text { - Clean any spills immediately. Spills should always decontaminate the area though } \\
\text { follow proper disposal procedures } \\
\text { - Remove and decontaminate all unnecessary equipment after using it and store } \\
\text { appropriately } \\
\text { - Check surfaces and tools before, during and after work periods. } \\
\text { - Document the cleaning status of each equipment in logbooks }\end{array}$ \\
\hline 14 & $\begin{array}{l}\text { - Always wear sterile gloves when working in the collection, transportation, } \\
\text { isolation, identification, characterization of the sample. } \\
\text { - Change gloves frequently, especially in DNA and RNA amplification on each } \\
\text { specimen } \\
\text { - Basically, try not to handle anything without gloves, }\end{array}$ \\
\hline 15 & $\begin{array}{l}\text { - Microbial laboratory set up is designed specifically that suitable for scientific } \\
\text { experiments. Written laboratory records for every cell culture. }\end{array}$ \\
\hline 16 & $\begin{array}{l}\text { - Use a standard surgical mask to protect active respiratory track oral droplet direct } \\
\text { contact. } \\
\text { - should avoid touching the mask while preparing specimens. } \\
\text { - Do not talk inside the culture room. If so, use masks. Your mouth has fungi that } \\
\text { can be a possible source. }\end{array}$ \\
\hline 17 & $\begin{array}{l}\text { - Spray over your hands with appropriately diluted alcohol (70\%) up to your elbows, } \\
\text { during cell handling. } \\
\text { - Wash hands thoroughly with antiseptic soap and warm water before entering and } \\
\text { leaving the laboratory. The control of all types of contaminations start from personal } \\
\text { hygiene of hands and travel through all steps of culture. }\end{array}$ \\
\hline 20 & $\begin{array}{l}\text {-Avoid culturing of animal, human and microbial cell together within the same } \\
\text { incubator. } \\
\text {-Incubators are to be cleaned with recommended solution. It may be daily, weekly } \\
\text { and monthly. }\end{array}$ \\
\hline 21 & $\begin{array}{l}\text { - Attain room ventilation system that replaces fresh air in air filtration path. } \\
\text { - Air filtration and air change rates should be set to ensure that the defined clean } \\
\text { room class is attained. } \\
\text { - Airflow over critical areas should be uni-directional (laminar flow) at a velocity } \\
\text { sufficient to sweep particles away from filling/closing area. } \\
\text { - Air handling ducts should be cleaned and properly maintained and pre-filters } \\
\text { venting the air into the culture room should be replaced frequently }\end{array}$ \\
\hline 22 & $\begin{array}{l}\text { - When entering the cabinet, wipe down the surface with } 70 \% \text { ethanol } \\
\text { - Allow the air in the hood to circulate for } 5 \text { minutes before use. This will allow any } \\
\text { contaminants to hopefully enter the laminar flow and not end up in your media or } \\
\text { dishes. }\end{array}$ \\
\hline
\end{tabular}




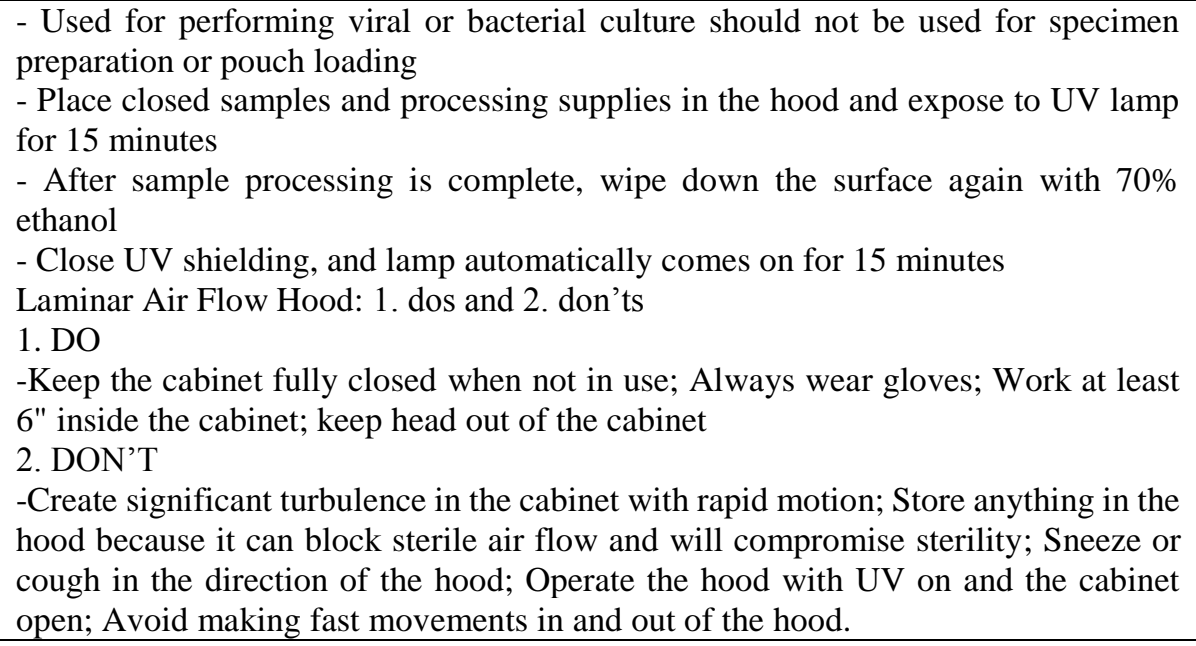

\section{EFFECTS OF CONTAMINANTS ON CELL/MICROBIAL CULTURE AND OTHERS}

- Competing for nutrients and they are hinders for cell growth and proliferation

- Expositing cells to unwanted primary and secondary metabolites utilization and production respectively.

- Altering levels of protein, RNA, or DNA synthesis in terms of quantity and quality

- Changing gene expression, cell signaling, morphology and physiology

- Damaging membranes and organelles at the high level

- Causing mutations and chromosomal changes

- Destroying the natural microbial community structure and function

- Devastating the growth and characteristics of the cultures. It has adverse effects on inhibition of cell metabolism

- Damaging of valuable products and boring to get pure and viable culture.

- Contributing several risks /outbreaks of laboratory - acquired infections for technicians, researchers, healthcare workers and patients. Immune deficiency individuals are sensitive to severe human disease. The persistent pathogens the mode of transmission is huge in number

- Influencing on signal transduction

- Serving as public health concern it becomes available for a biological weapons.

- Causing severe economic challenges registered

- Losing the quality of research outcome and inaccurate or erroneous experimental results recorded

- Losing time, money (for cells, culture vessels, media, and sera), and effort (spent developing cultures and setting up experiments) already happen

- Frustrating feelings become occurred and Personal embarrassment also.

To summarize, the three best practices to maintain the integrity and accuracy of cell cultures, and promote a safe laboratory environment. First, use appropriate lab design. Second, use correct culturing procedures. Thirdly, use suitable cleaning procedures. It is the best guarantee for successful completion.

\section{THE FUTURE DIRECTION OF CONTAMINATES}

Laboratories require investigation review process to identify unusual numbers of false-positive cultures and a mechanism to determine the possible causes profoundly. As a minimum, it must be conducted through monthly or annually follow up period. Continuing communication among clinicians, laboratory technicians and researchers remains critical in the interpretation of unusual findings that develop from cross and self-contamination. In the future, three activities are attentively supported. That is: (I). Identity of the taxa through various well accepted scientific methods like metabolic and genetic fingerprinting. 
(II). Sources of potential hazards based on the isolation and identification of indicator microorganisms, (III). Development of methods for the treatment of microbiological hazards.

When starting to explore contaminates. It will be promising for further outcomes such as antibiotic production, medical value, biotechnological research and antimicrobial activity for drug resistance and susceptibility assays. In the future, It is very important to generate full scientific knowledge through continues research even can make a survey in the field of microbial diversity (community, functional and structural) pattern. Additional systematic studies will be performed in the area in order to ignore frustrating and devastating idea: To accomplish unique and get suitable viable pure culture. The merit will greater than the disadvantage part of it.

\section{CONCLUSION}

Generally, the present study reported that laboratory equipment and environment act as the potential sources of contamination which exhibit high concentration. To solve the problem various methods must be applied. Nowadays, Formulate, implement and revalidate protocols at regular intervals are most acceptable and affordable option. Establishment of control points is essential for all. Appropriate and careful management strategy considering as a critical points step by step starting right from collection of sample to their processing can significantly minimize contamination load. Lastly, concluded that contaminants can cause loss research work and interfere with the normal arrangement or functioning of central cell dogma. For this evidence, this paper helps to address short and long-term effect of contaminants in the microbial laboratory. To sum up, contamination can be totally eliminated, it can be managed to reduce both its frequency of occurrence and seriousness of its consequences by introducing good laboratory practice.

\section{RECOMMENDATION}

Always seasonal survey and continued surveillance should be conducted on physical, chemical and microbial assemblages to maintain the purity of culture. Practical based subsequent control mechanisms should deem to remove the risk of a cross-contamination.

\section{ACKNOWLEDGMENTS}

I would like to thankful Ethiopian Biodiversity Institute staff for providing us necessary facilities during this study. This work was carried out in collaboration between authors. All authors read and approved the final manuscript.

\section{REFERENCES}

[1] Amena Mahamood and Shakir Ali (2017). Microbial and Viral Contamination of Animal and Stem Cell Cultures: Common Contaminants, Detection and Elimination. Journal of Stem Cell Research \& Therapeutics. 2(5): 00078- 00078. DOI: 10.15406/jsrt.2017.02.00078.

[2] Borst. A, A. T. A. Box, A. C. Fluit (2004). False-Positive Results and Contamination in Nucleic Acid Amplification Assays: Suggestions for a Prevent and Destroy Strategy. European Journal of Clinical Microbiology and Infectious Diseases.23(4): 289-299.

[3] Chandrahas S, Nair A, Sahu SB, Sahasrabudhe SA, Kumar A, Gupta AK, Shende RK (2015). Critical sources of bacterial contamination and adoption of standard sanitary protocol during semen collection and processing in Semen Station. Veterinary World, 8(5):631-635.

[4] Erin R. Sanders (2012). Aseptic Laboratory Techniques: Plating Methods .Journal of Visualized Experiments. (63): 1-18, e3064. Doi: 10.3791/3064.

[5] Hadir EL-Kady (2017). Microbial Contamination of Mobile Phones in the Medical Laboratory Technology Department of a Private University in Alexandria, Egypt. Int. J. Curr. Microbiol. App. Sci. 6(6): 200-211. https://doi.org/10.20546/ijcmas.2017.606.024.

[6] Hans G. Drexler* \& Cord C. Uphoff (2002). Mycoplasma contamination of cell cultures: Incidence, sources, effects, detection, elimination, prevention. Cytotechnology. 39: 75-90.

[7] Hsuan Jung; Shih-Yee Wang; I-Wen Yang, Ding-Wei Hsueh, Wei-Ju Yang, Tzu-Hao Wang, Hsin-Shih Wang (2003). Detection and Treatment of Mycoplasma Contamination in Cultured Cells. Chang Gung Med J. 26 (4):250-258.

[8] Jaya Madhuri R, Saraswathi M, Mahitha G, Bhargavi M, Deepika S,Vijaya Lakshmi G (2015). Bacterial contamination of mobile phones and computers in microbiological laboratories. European Journal of Biotechnology and Bioscience. 3(9): 51-55. 
[9] Jayashree Konar, Sanjeev Das (2013). Common Contaminants of Bacteriology Laboratory: Microbiological Paramores. International Journal of Pharmaceutical. 2(11): 36-37.Science Invention ISSN (Online): 2319 6718, ISSN (Print): 2319 - 670X.

[10] Laleh Nikfarjam, Pravanesh Farzaheh (2012). Prevention and Detection of Mycoplasma Contamination in Cell Culture. Cell Journal. 13(4): 203-212.

[11] Mado Vandewoestyne, David Van Hoofstat, Sabine De Groote, Nicky Van Thuyne, Saskia Haerinck, Filip Van Nieuwerburgh, and Dieter Deforce (2011). Sources of DNA Contamination and Decontamination Procedures in the Forensic Laboratory. J Forensic Res, 2: 1-3. http://dx.doi.org/10.4172/2157-7145. ISSN: 2157-7145 JFR,

[12] Mahmoudabadi A.Z (2007). Laboratory instrument contamination with dermatophytes - a risk for dermatophytosis. Letters in Applied Microbiology. 44: 112-113. doi:10.1111/j.1472-765X.2006.02025.x.

[13] Marcin £OOE, Agata CZY, Eugenia SELL, Alicja WÊGRZYN, Peter NEUBAUER, Grzegorz WÊGRZYN (2004). Bacteriophage contamination: is there a simple method to reduce its deleterious effects in laboratory cultures and biotechnological factories? .J. Appl. Genet. 45(1):111-120.

[14] Miguel Mart1'nez, Darı'o Garc1'a de Viedma et al,. (2006). Impact of Laboratory Cross-Contamination on Molecular Epidemiology Studies of Tuberculosis. Journal of clinical microbiology, 44(8):2967-2969.

[15] Muhammad Ghayoor, Abdul Qadoos, Sulaiman Bahadar, Azam Hayat, Muhammad Daud, Adil Hassan, Fahad Ali, Aurang Zeb, Khalil Ur Rahman, Abdul Wahab, Zeenat Fatima Khattak and Baharullah khattak (2015). Isolation and Identification of Common Contaminants Bacteria from Working Area in Microbiology Laboratory. Journal of Bio-Molecular Sciences (JBMS) 3(2): 74-78.

[16] Odutayo O.I, Amusa, O.O, et al., (2007). Determination of the source of microbial contamination of Cultured Plant Tissues. Plant Pathology Journal 6(1): 77-81. ISSN 1812-5387.

[17] Pantopikou K, Papasotiriou I (2017). Detection and Identification of Bacterial Contamination in Blood Samples from Cancer Patients. Arch Clin Microbiol. 8(3:42): 1-5. DOI: 10.4172/1989-8436.100042

[18] Sarah B. Carey, Adam c. payton, and Stuart f. McDaniel (2015). A method for eliminating bacterial contamination from in vitro moss cultures. Applications in Plant Sciences. 3(1): 1400086.

[19] Sautour M, Dalle F, Olivieri C, L'ollivier C, Enderlin E, Salome E, Chovelon I, Vagner O, Sixt N, FrickerPap V, Aho S, Fontaneau O, Cachia C, Bonnin A (2009). A prospective survey of air and surface fungal contamination in a medical mycology laboratory at a tertiary care university hospital. Am J Infect Control? 37(3):189-94. Doi: 10.1016/j.ajic.2008.06.009. Epub 2008 Dec 6.

[20] Silvia. L Munoz-Price, Kristopher L. Arheart, John P. Mills, Timothy Cleary, Dennise DePascale, Adriana Jimenez, Yovanit Fajardo-Aquino, Gabriel Coro, David J. Birnbach, David A. Lubarsky PlumX Metrics_(2012). Associations between bacterial contamination of health care workers' hands and contamination of white coats and scrubs. Am J Infect Control? 40(9): e245-e248. DOI: https://doi.org/10.1016/j.ajic.2012.03. 032.

[21] Sonam Thaore, NiranjanDesai, S. R. Srinidhi*, Pallavi Surwade (2016). MICROBIAL CONTAMINATION OF LAB COATS WHILE PERFORMING ENDODONTIC TREATMENT. 7(6): 1-6. ISSN: 0976-3104.

[22] Stacey GN. (2011). Cell culture contamination. Methods Mol Biol. 731:79-91. Doi: 10.1007/978-1-61779-080-5_7.

[23] Yatin Mehta, Abhinav Gupta, Subhash Todi, Myatra S, D. P. Samaddar, Vijaya Patil, Pradip Kumar Bhattacharya, Suresh Ramasubban (2014). Indian Journal of Critical Care Medicine. 18(30):149-163.

[24] Wang Xin Ling, SONG Juan, SONG Qin Qin, YU Jie, LUO Xiao Nuan, WU Gui Zhen, and HAN Jun (2016).Viral Contamination Source in Clinical Microbiology Laboratory. Biomed Environ Sci. 29(8): 609-611.

[25] www.corning.com /life science

[26] www.mlo-online.com

[27] www.promega.com

[28] www.BioFireDx.com

[29] www.atcc.org

Citation: Endeshaw Abatenh, Birhanu Gizaw, Zerihun Tsegaye, " Contamination in a Microbiological Laboratory", International Journal of Research Studies in Biosciences (IJRSB), vol. 6, no. 4, pp. 7-13, 2018. http://dx.doi.org/10.20431/2349-0365.0604002

Copyright: (C) 2018 Authors. This is an open-access article distributed under the terms of the Creative Commons Attribution License, which permits unrestricted use, distribution, and reproduction in any medium, provided the original author and source are credited. 